\title{
Exploitation problems of turbochargers installed on engines fuelled by gas
}

\author{
Article describes two selected operational problems of turbochargers installed on gas engines. \\ Key words: turbocharger, breakdown, operation
}

\section{Problemy eksploatacyjne turbosprężarek zainstalowanych na silnikach zasilanych gazem}

\author{
Opracowanie zawiera opis dwóch wybranych zagadnień zwiazanych z eksploatacja turbosprężarek $w$ połaczeniu \\ z tłokowym silnikiem o zapłonie iskrowym zasilanym gazem. Zagadnienia opisuja problemy eksploatacyjne, z jakimi \\ stykaja się eksploatatorzy silników. \\ Słowa kluczowe: turbosprężarka, awaria, eksploatacja
}

\section{Admission}

For nearly 100 years associating the internal-combustion engine as machines about the cyclical work with the machine is enjoying the unremitting popularity about the continuous work a turbocharger is which. At first idea turbo had charging up for the task providing with the higher ceiling of the work for piston air engines. At present getting is focusing the attention of engineers and designers as of the best indicators of the functioning of the internal-combustion engine that is minimizing the fuel consumption, limiting emission of toxic combustion products and the increase in the general efficiency of driving teams. It is forming in the main measuring cup with the need of the improvement to fill the cylinder of the internal-combustion engine with the working substance and it next is forcing into applying charging up the simplest way realizing above assumptions. Opposite for these expectations producers of turbochargers left designing and producing organizing about the very great technological progress and about the more and more high efficiency. ABB Turbocharging is a market leader assuring machines for gas engines more $500 \mathrm{~kW}$.

Search better and better solution is also extorting the increase in the level of the technical support and the necessity of the increase in the awareness about the risk which is accompanying of advanced exploitations structurally of devices. This study contains the description of two problems associated with the exploitation of turbochargers installed on gas engines in the backrest for experience collected in the process of service and exploitation works.

\section{Structure of turbocharger}

Knowing structure of turbocharger allows for their correct exploitation and this allows for economic and failurefree work of driving or power-generating teams.

In Fig. 1 a diameter was described - with the description - at present using turbochargers of TPS series produced by ABB Turbocharging.

\section{Wstęp}

Od blisko 100 lat cieszy się niesłabnącą popularnością skojarzenie silnika spalinowego jako maszyny o pracy cyklicznej z maszyną o pracy ciągłej, jaką jest turbosprężarka.

Początkowo idea turbodoładowania miała za zadanie zapewnienie wyższego pułapu pracy tłokowym silnikom lotniczym. Obecnie uwagę inżynierów i konstruktorów skupia uzyskanie jak najlepszych wskaźników pracy silnika spalinowego a mianowicie zminimalizowanie zużycia paliwa, ograniczenie emisji toksycznych produktów spalania oraz wzrost ogólnej sprawności zespołów napędowych. Wiąże się to $\mathrm{w}$ głównej mierze $\mathrm{z}$ koniecznością poprawy napełnienia cylindra silnika spalinowego czynnikiem roboczym a to z kolei wymusza stosowanie doładowania jako najprostszego sposobu realizującego powyższe założenia.

Naprzeciw tym oczekiwaniom wyszli producenci turbosprężarek projektując i produkując urządzenia o bardzo dużym zaawansowaniu technologicznym i o coraz wyższej sprawności ogólnej. Liderem na rynku jest ABB Turbocharging zapewniając urządzenia dla silników gazowych powyżej $500 \mathrm{~kW}$.

Poszukiwanie coraz lepszych rozwiązań wymusza również wzrost poziomu obsługi technicznej oraz konieczność wzrostu świadomości o ryzyku, jakie towarzyszy eksploatacji zaawansowanych konstrukcyjnie urządzeń.

Opracowanie to zawiera opis dwóch problemów związanych z eksploatacją turbosprężarek zainstalowanych na silnikach gazowych w oparciu o doświadczenia zebrane w trakcie prac serwisowych i eksploatacyjnych.

\section{Budowa turbosprężarki}

Znajomość budowy turbosprężarek pozwala na ich prawidłowa eksploatacje a to z kolei pozwala na ekonomiczną i bezawaryjną pracę zespołów napędowych lub prądotwórczych.

Na rys. 1 przedstawiono przekrój - wraz z opisem obecnie stosowanej turbosprężarki serii TPS produkowanej przez ABB Turbocharging. 


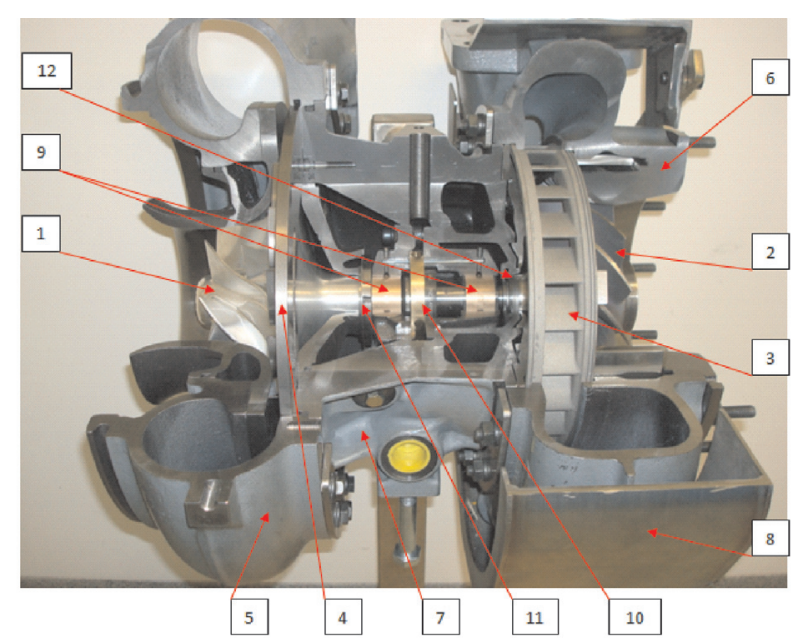

Fig. 1. Cutaway of typical turbocharger applied at present in gas engines: 1 - compressor wheel, 2 - turbine wheel, 3 - nozzle ring, 4 - diffuser, 5 - compressor casing, 6 - turbine casing, 7 - bearing casing, 8 - protection, 9 - radial bearings, 10 - thrust bearing, 11 - compressor sealing area, 12 - turbine sealing area

Rys. 1. Przekrój współczesnej turbosprężarki stosowanej obecnie w silnikach gazowych: 1 - wirnik sprężarki, 2 - wirnik turbiny, 3 - kierownica spalin, 4-dyfuzor, 5-korpus wirnika sprężarki, 6-korpus wirnika turbiny, 7 -korpus łożyskowy, 8-osłona, 9- Łożyska promieniowe, 10 - tożysko oporowe, 11 - uszczelnienie wirnika sprężarki, 12 - uszczelnienie wirnika turbiny

\section{Influence of emergency alloys of the engine on the work of the turbocharger}

In order to clarify consequences of emergency alloys of the engine work of the turbocharger, particularly in the area of the rotor of the turbine, one should introduce distribution of the thermal energy to the specificity.

Main stream of the thermal energy $\mathrm{Q}_{1}$ reaching to working space of the rotor turbine in the exhaust stream leaving cylinders of the engine. Size stream $Q_{1}$ is dependent of the mass rate flow of the exhaust fumes and the temperature $T_{d}$ (temperature before turbocharger). One should remind that temperature measured behind cylinders of the engine is lower than temperature $T_{d}$ for size of the increase temperature $\Delta T$ resulting from the phenomenon of the changeable pressure (of pulsation) on the intake into the turbine and from the phenomenon of piling the pressure up resulting from the reduction of the diameter of the intake of the exhaust fumes into the turbine.

For example for nominal burdens in engines about (own evidence):

- CI $\Delta \mathrm{T}$ is equaling $(100-150)^{\circ} \mathrm{C}-\mathrm{T}_{\mathrm{d} \text { max }}$ is equaling about $550^{\circ} \mathrm{C}$

- SI fed with fermentation gas (with biogas) or with mine methane $-\Delta \mathrm{T}$ is equaling $(150-250)^{\circ} \mathrm{C}$ and $\mathrm{T}_{\mathrm{d} \text { max }}$ can achieve extremely $700^{\circ} \mathrm{C}$.

After settling parameters of work of the driving team thermal power (lost power) intercepted by the rotor of the turbine is only toward the direct of the turbine dispersed and there is taking back by the stream of oil greasing sliding bearings. One can estimate count size of the power which is taking back by oil from the relation:

\section{Wpływ awaryjnych stopów silnika na pracę turbosprężarki}

Aby naświetlić konsekwencje awaryjnych stopów silnika na pracę turbosprężarki, a szczególnie w obszarze wirnika turbiny, należy przybliżyć specyfikę dystrybucji energii cieplnej.

Główny strumień ciepła $Q_{1}$ dociera do przestrzeni roboczej wirnika turbiny w strumieniu spalin opuszczających cylindry silnika. Wielkość strumienia $\mathrm{Q}_{1}$ jest uzależniona od masowego natężenia przepływu spalin oraz temperatury $T_{d}$ (temperatura przed turbosprężarką). Należy przypomnieć, że temperatura mierzona za cylindrami silnika jest niższa od temperatury $\mathrm{T}_{\mathrm{d}}$.

Dla przykładu dla obciążeń nominalnych w silnikach o (dane własne):

- ZS $\Delta \mathrm{T}$ wynosi $(100-150)^{\circ} \mathrm{C}-\mathrm{T}_{\mathrm{d} \max }$ wynosi około $550^{\circ} \mathrm{C}$, - ZI zasilanych gazem ziemnym $\Delta \mathrm{T}$ wynosi $(120-170)^{\circ} \mathrm{C}$,

- ZI zasilanych gazem fermentacyjnym (biogazem) lub metanem kopalnianym $-\Delta \mathrm{T}$ wynosi $(150-250)^{\circ} \mathrm{C}$ i $\mathrm{T}_{\mathrm{d} \max }$ ekstremalnie może osiągnąć $700^{\circ} \mathrm{C}$.

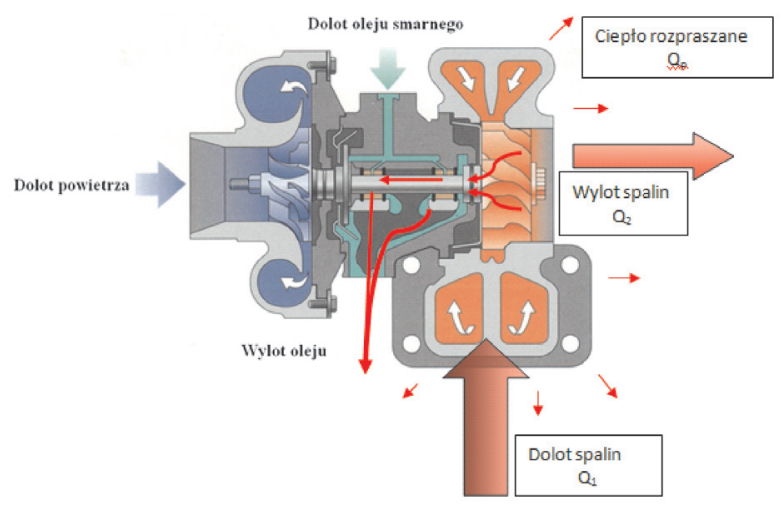

Fig. 2. Scheme of the flow the warmth in the turbine area (the arrows worms depicts directions of the flow of the warmth)

Rys. 2. Schemat przeplywu ciepła w obszarze wirnika turbiny (strzałki obrazuja kierunki przeptywu ciepta)

Po ustaleniu się parametrów pracy zespołu napędowego moc cieplna przechwytywana przez wirnik turbiny rozpraszana jest głównie w kierunku wału turbiny a tam odbierana jest przez strumień oleju smarującego łożyska ślizgowe.

Wartość tej mocy, jaka jest odbierana przez olej można szacunkowo policzyć z zależności empirycznej (dla turbosprężarek nie chłodzonych cieczą) [1]:

$$
\mathrm{N}_{\mathrm{so}}=\mathrm{N}_{\mathrm{e}} \cdot 0,02[\mathrm{~W}]
$$

gdzie: $\mathrm{N}_{\mathrm{so}}-$ moc cieplna przekazywana do oleju smarnego [W], $\mathrm{N}_{\mathrm{e}}-$ moc efektywna silnika [W].

Ciepło $\mathrm{Q}_{2}$ to pozostałe ciepło unoszone ze strumieniem spalin (pomniejszone w głównej mierze o ciepło przekazane do napędu turbiny). Ciepło $Q_{0}$, ulegające rozproszeniu poprzez obudowę turbiny można pominąc ze względu na niewielką wartość (około 1\% ciepła, jakie dociera do turbosprężarki).

Doprowadzanie do natychmiastowego zatrzymania silnika z pracy pod obciążeniem bez biegu luzem unie- 


$$
\mathrm{N}_{\mathrm{so}}=\mathrm{N}_{\mathrm{e}} \cdot 0.02[\mathrm{~W}]
$$

where: $\mathrm{N}_{\mathrm{so}}-$ power of losses sent to spreadable oil [W], $\mathrm{N}_{\mathrm{e}}$ - effective power of engine [W].

Difference between stream $Q_{1}$ and stream $Q_{2}$ is a rate of the efficiency, with which an energy from the exhaust stream exchanged next for the mechanical energy necessary for the drive of the rotor of the compressor is being taken. One can omit warmth $\mathrm{Q}_{0}$ undergoing dispersing the turbine through the casing on account of the little value (about $1 \%$ warmth which is reaching the turbocharger).

Correct cooling hot elements of the turbocharger is making impossible leading the engine to the immediate apprehension from work under burdening without gear with gap to the acceptable level of temperatures. Additionally having the determined inertia rotors of the turbocharger are whirling longer time at limited greasing, handing warmth to little layer oil which is not in proper way changed. Effect of this situation is adverse phenomenon of settling carbon deposit around hot elements. Elements which will be in direct vicinity of the rotor turbine:

- radial bearing,

- bung of the embankment of the turbine,

- ring-shaped sealing

Repeatedly the appearing situation with emergency stopping the engine causes reducing gap between the bearing and the bung, and the diameter open to reducing of spreadable ducts (Fig. 2). In extremely situation is pursuing the flow of oil for erasing the turbocharger for lack after through the bearing, what causes switching engine off from the exploitation.

A sedimentation of deposits is a separate issue which is requiring an explanation of burnt oil around sealing the ringshaped rotor of the turbine (Fig. 3 and 4). Developing with deposit of this area cause impediments in correct of flow the excess oil in direct of confluence hole from the bearing.

In consequence a sealing ring is stopping correctly working (the sealing ring is a mechanical-labyrinthine sealing), carbon deposits are erasing essential gap between the embankment of the turbine and the ring what is leading to the leakiness (Fig. 5). Leaks of oil for the combustion body of the turbine periodically being able to filter appear after between connections outside (peculiarly it is easy to observe it during the stop of the engine with the pump turned on periodically preliminary pre lubricating) or cause characteristic light blue smoking out the exhaust fumes.

\section{Influence quality of engine oil on elements of turbocharger}

A care of the correct state and a cleanness of oil greasing the engine with accessories are the second important issue. Minimizing the friction and receipt of the warmth from cooperating elements are main task engine oil. It is also acting as the sealing, this function of oil has the deciding influence on this quality. A direct contact with combustion products causes absorptions of mechanical and chemical pollutants. możliwia prawidłowe schłodzenie gorących elementów turbosprężarki do akceptowalnego poziomu temperatur. Dodatkowo wirniki turbosprężarki mając określoną bezwładność wirują dłuższy czas przy ograniczonym smarowaniu, oddając ciepło do niewielkiej warstwy oleju, która nie jest w należyty sposób wymieniana. Efektem tej sytuacji jest niekorzystne zjawisko osadzania skoksowanego oleju wokół gorących elementów. Narażone na to zjawisko są elementy będące $\mathrm{w}$ bezpośrednim sąsiedztwie wirnika turbiny:

- łożysko promieniowe,

- czop wału turbiny,

- uszczelnienie pierścieniowe.

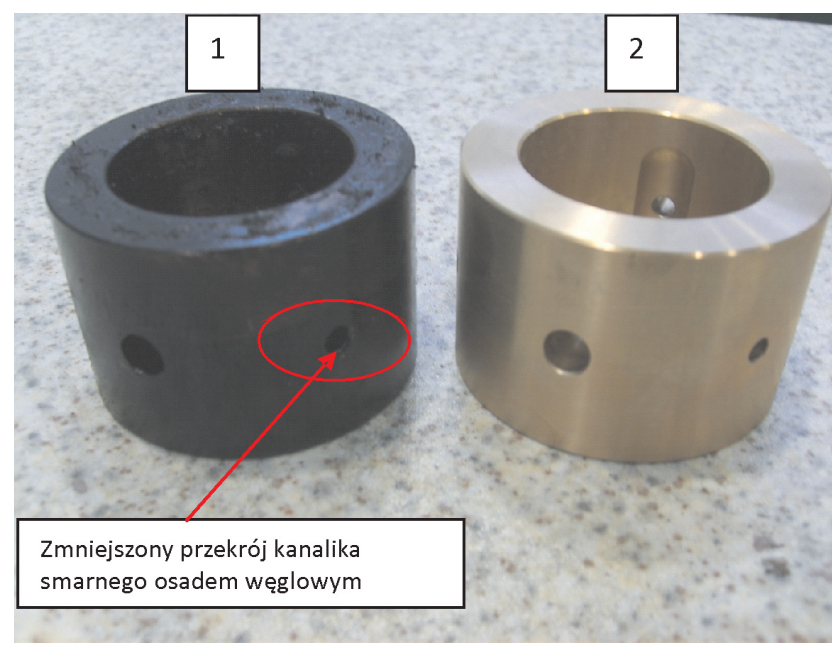

Fig. 3. Bearing covered with deposit [1], new bearing [2]

Rys. 3. Łożysko pokryte osadem węglowym [1], tożysko nowe [2]

Nagminnie pojawiająca się sytuacja z zatrzymywaniem awaryjnym silnika prowadzi do zmniejszenia luzu pomiędzy łożyskiem a czopem, oraz do zmniejszania czynnego przekroju kanalików smarnych (rys. 3). W ekstremalnej sytuacji dochodzi do zatarcia turbosprężarki z braku przepływu oleju po przez łożysko, co powoduje wyłączenie silnika z eksploatacji.

Osobnym zagadnieniem, które wymaga wyjaśnienia jest sedymentacja osadów ze spalonego oleju wokół uszczelnienia pierścieniowego wirnika turbiny (rys. 4 i 5). Zabudowanie osadem tego obszaru powoduje utrudnienia w prawidłowym spływu nadmiaru oleju w kierunku otworu spływowego z korpusu łożyskowego.

W konsekwencji przestaje prawidłowo pracować pierścień uszczelniający (pierścień uszczelniający jest uszczelnieniem mechaniczno-labiryntowym), osady węglowe kasują niezbędny luz pomiędzy wałem turbiny a pierścieniem co prowadzi do nieszczelności (rys. 6).

Pojawiają się wycieki oleju do korpusu spalinowego turbiny okresowo mogące się przesączać po między połączeniami na zewnątrz (szczególnie łatwo to zaobserwować podczas postoju silnika z włączaną okresowo pompą wstępnego przesmarowania) lub powodują charakterystyczne błękitne zadymienie spalin. 


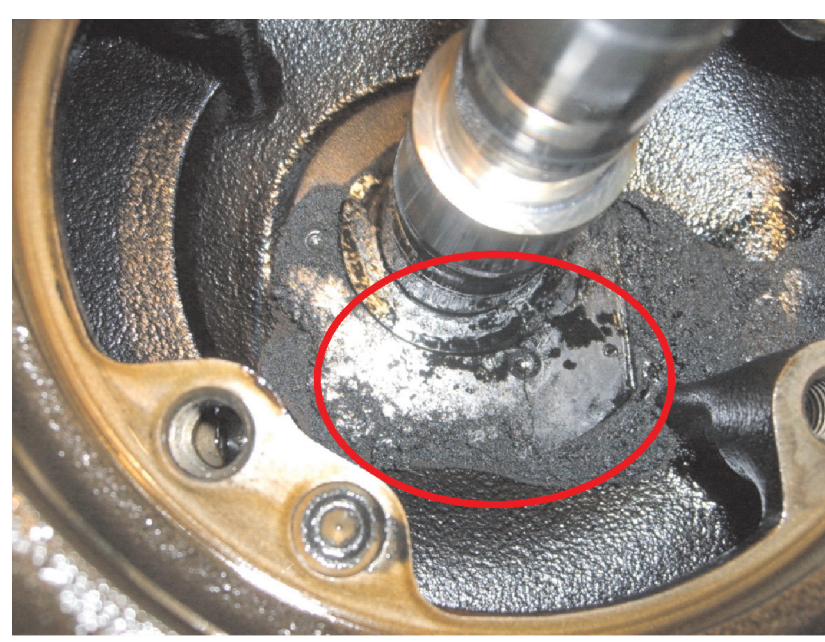

Fig. 4. Bearing casing carbon deposit Rys. 4. Depozyt ze skoksowanego oleju wewnątrz korpusu łożyskowego

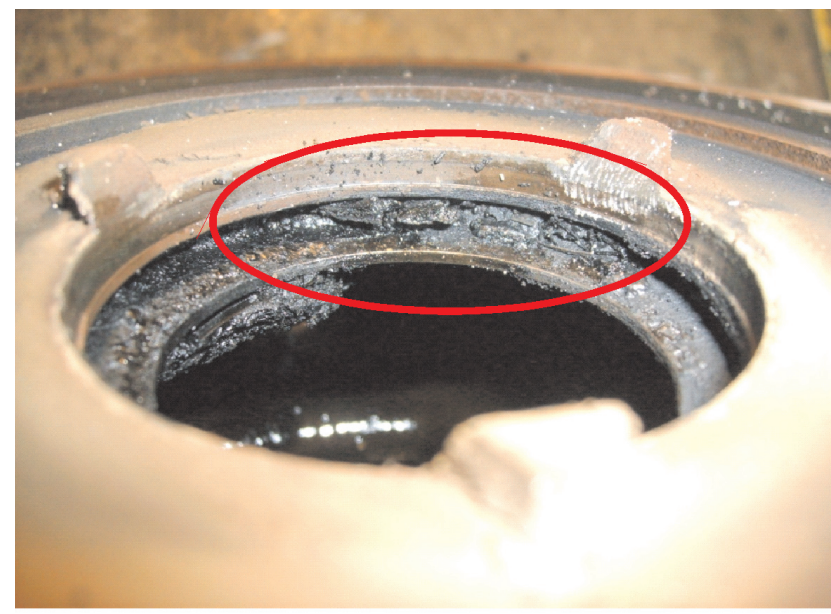

Fig. 5. Turbine sealing area carbon deposit

Rys. 5. Osady węglowe w obszarze pierścienia uszczelniającego turbinyv

The majority of particulates getting to oil is being removed in the system of the filtration of oil, but a certain amount always circulates in circulation of the engine settling in channels and spaces, in which the speed of the flow considerably is dropping. These settlements are able periodically to free on self (under the influence of changes temperature, viscosities oil, changes level the vibration of the driving team) and penetrating into river beds cause damage. Structure of bearings is facilitating turbochargers absorption of hard particles deep into structures of material. Sliding bearings of contemporary turbochargers are most often of different grades of bronze or brass made (Fig. 7; 10), of which relatively the soft structure allows for sticking of deposits. A specific structure is formed like grind wheel which causes losses in bungs of the embankment of the turbocharger and directly cooperating elements (Fig. 8; 9). The most breakdowns caused by the higher described occurrence concern driving teams fed with gas from council stockpiles and with fermentation biogas. In both these cases an explicitly increased content of silica in oil was stated.

\section{Wpływ jakości oleju silnikowego na elementy turbosprężarki}

Drugim ważnym zagadnieniem jest dbałość o prawidłowy stan i czystość oleju smarującego silnik wraz z osprzętem. Głównym zadaniem oleju w silniku jest zminimalizowanie tarcia oraz odbiór ciepła ze współpracujących elementów. Spełnia również rolę uszczelnienia, ta funkcja oleju ma decydujący wpływ na jego jakość. Bezpośredni kontakt $z$ produktami spalania powoduję absorpcję zanieczyszczeń mechanicznych i chemicznych.

Większość cząstek stałych przedostających się do oleju usuwana jest w systemie filtracji oleju, lecz pewna ilość zawsze krąży w obiegu silnika osadzając się w kanałach i przestrzeniach, w których prędkość przepływu znacząco spada. Osady te potrafią okresowo uwalniać się (pod wpływem zmian temperatury, lepkości oleju, zmian poziomu wibracji zespołu napędowego) i przedostając się do łożysk powodują uszkodzenia.

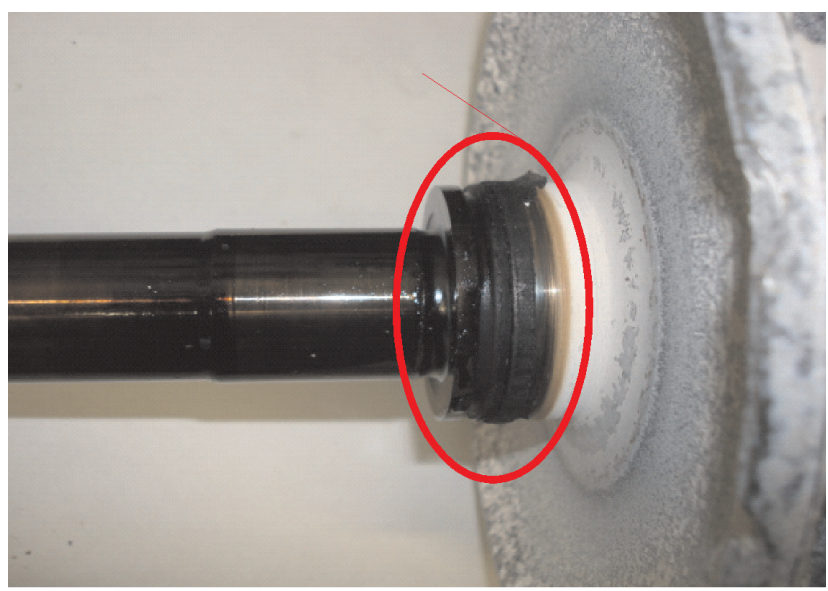

Fig. 6. Carbon deposit around piston ring of turbine side Rys. 6. Osady węglowe wokót pierścienia uszczelniającego wirnik turbiny

Konstrukcja łożyskowania turbosprężarek ułatwia absorpcję twardych cząstek w głąb struktury materiału. Łożyska ślizgowe współczesnych turbosprężarek wykonuje się najczęściej z różnych gatunków brązu lub mosiądzu (rys. 7, 10), którego stosunkowo miękka struktura pozwala na wbijanie się osadów. Tworzy się swoista struktura ściernicy, która powoduje ubytki w czopach wału turbosprężarki oraz elementach bezpośrednio współpracujących (rys. 8, 9).

Najwięcej awarii spowodowanych wyżej opisanym zjawiskiem dotyczy zespołów napędowych zasilanych gazem ze składowisk komunalnych oraz biogazem fermentacyjnym.

W obu tych przypadkach stwierdzono jednoznacznie podwyższoną zawartość krzemionki w oleju.

\section{Podsumowanie}

Znajomość opisanych powyżej problemów, jakie towarzyszą w trakcie eksploatacji zespołów napędowych zasilanych gazem w znacznym stopniu powinny wyostrzyć uwage obsługi i osób odpowiedzialnych za eksploatację. 


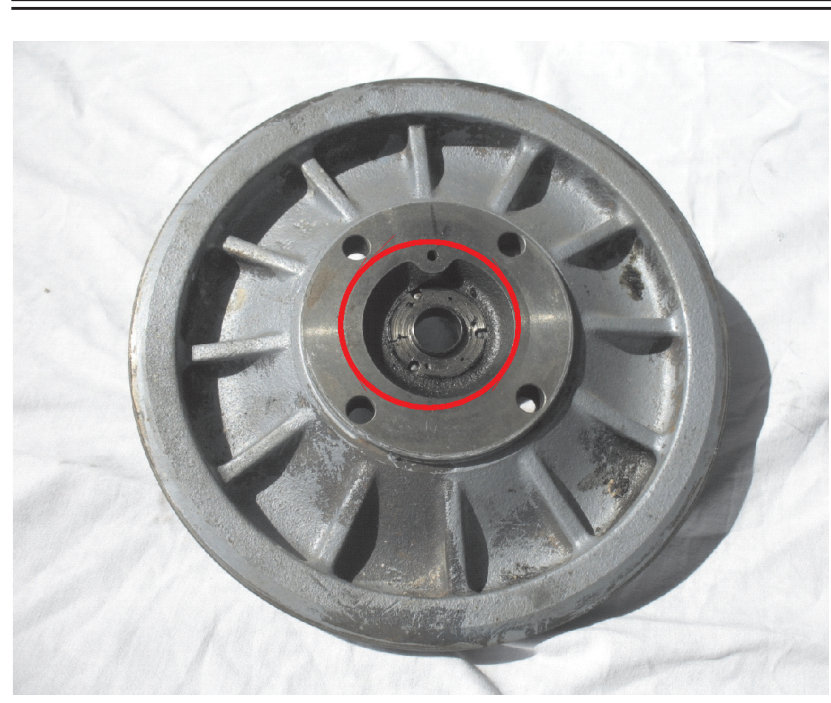

Fig. 7. Worn out thrust bearing - turbocharger TV 94

Rys. 7. Wytarty pierścień tożyska oporowego-turbosprężarka TV94

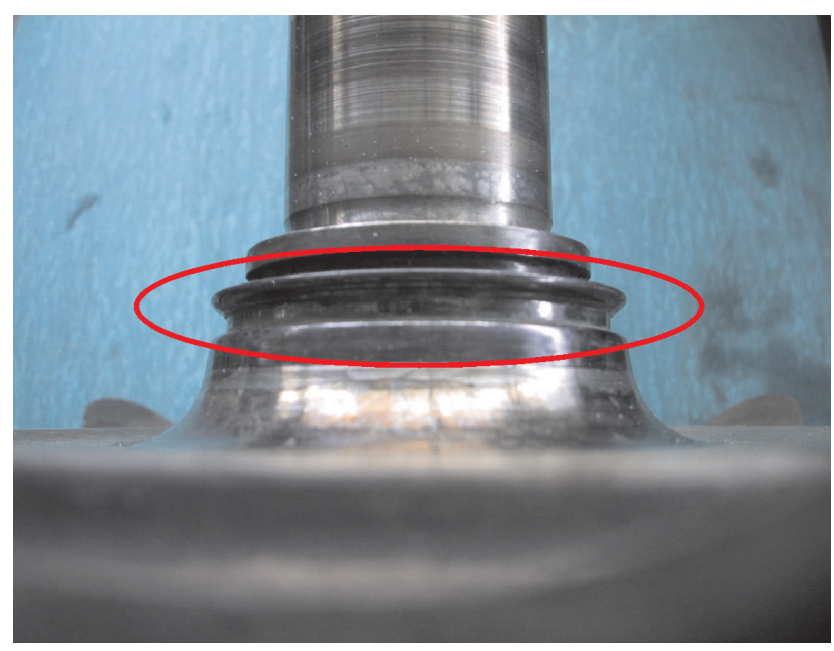

Fig. 9. Damages of piston ring area - turbine side

Rys. 9. Uszkodzenie powierzchni wspótpracy z pierścieniem uszczelniającym - wirnik turbiny

\section{Summary}

To a considerable degree they should sharpen the knowledge of driving teams described above problems which are accompanying in the process of the exploitation fed with gas attention of the service and the persons responsible for the exploitation. Competent evaluation of consequences which are accompanying and for emergency bases of the engine, whether the real supervision over the state and the quality of the engine oil and filters will allow in great measure to limit the failure frequency and to extend the use of sub-assemblies without the necessity of immediate repairs and to preserve emission of toxic compounds on the level assumed by the producer.

Exploitation problems of turbochargers installed on engine fed with gas - exploitation ailments.

The study contains the description two beloveds of issues associated with the exploitation of turbochargers in combination with the piston engine about the spark ignition with fed gas. Issues are describing exploitation problems exploiters of engines are encountering which.

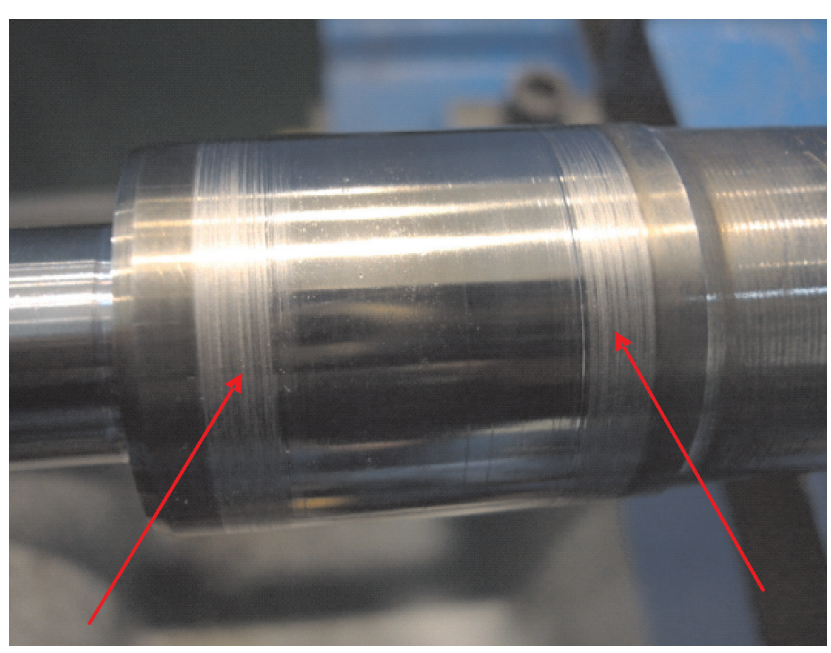

Fig. 8. Surface damages of the turbine shaft

Rys. 8. Uszkodzenia powierzchni ślizgowej wału wirnika turbiny

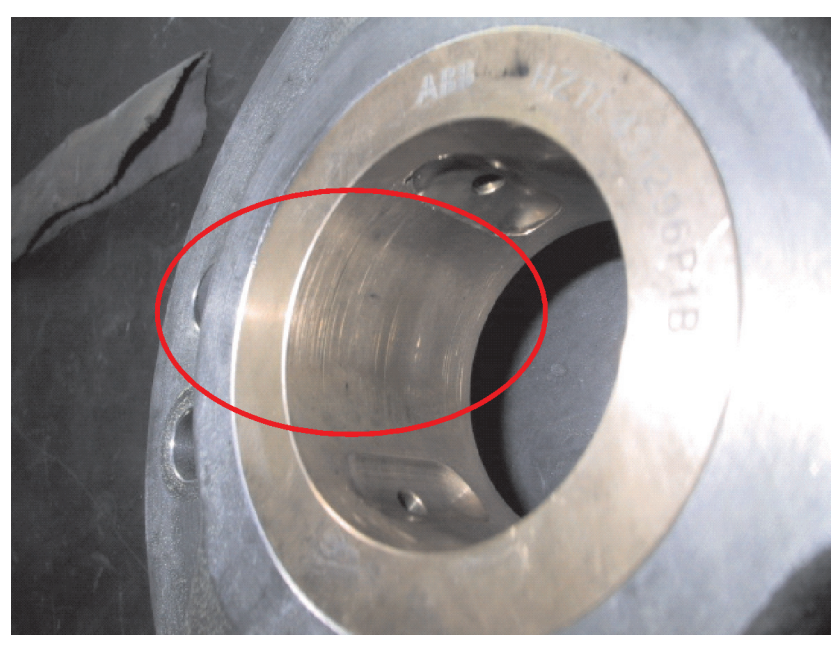

Fig. 10. Damages of inner surface of the radial bearing

Rys. 10. Uszkodzenia powierzchni ślizgowej łożyska promieniowego

Umiejętna ocena konsekwencji, jakie towarzyszą awaryjnym stopom silnika, czy właściwy dozór nad stanem i jakością oleju silnikowego i filtrów pozwoli w znacznej mierze ograniczyć awaryjność i wydłużyć eksploatację podzespołów bez konieczności natychmiastowych napraw oraz zachować emisję toksycznych związków na założonym przez producenta poziomie.

Paper reviewed/Artykut recenzowany

\section{Bibliography/Literatura}

[1] Summary Operation Manual of ABB Turbocharger.

Mr. Robert Fabjanowicz, MSc., MEng. - Service Workshop Manager of ABB Turbocharging, ABB Sp. z o.o., Gdańsk, Poland.

Mgrinz. Robert Fabjanowicz-Service Workshop Manager of ABB Turbocharging, ABB Sp. z o.o., Gdańsk, Polska.

e-mail: robert.fabjanowicz@pl.abb.com 